\title{
Effect of Storage Time and Temperature on Salivary Total Antioxidant Capacity, Total Oxidant Status, and Oxidant Stress Index
}

\section{Utjecaj vremena i temperature na ukupni antioksidacijski kapacitet pri čuvanju sline, ukupni oksidacijski status i indeks oksidacijskog stresa}

\begin{abstract}
Post-Graduate Program in Dentistry, Stomatology Department, Federal University of Paraná, Curitiba, PR, Brazil.
Poslijediplomski program dentalne medicine, Odjel za dentalnu medicinu Saveznoga sveučilišta u Parani, Curitiba, PR, Brazil

2 Stomatology Department, Oral Biochemistry Laboratory - LABIO, Universidade Federal do Paraná, Curitiba, PR, Brazil.

Odjel za dentalnu medicinu, Laboratorij za oralnu biokemiju - LABIO Saveznoga sveučilišta u Parani, Curitiba, PR, Brazil
\end{abstract}

\section{Abstract}

Objective: The aim of this study was to compare the effects of short-term storage in two different temperatures on stability of salivary total antioxidant capacity (TAC), total oxidant status (TOS) and oxidant stress index (OSI). Material and methods: Saliva samples were collected from twenty healthy volunteers for the study. An aliquot was selected for immediate analysis and the rest was stored at $-20^{\circ} \mathrm{C}$ and $-80^{\circ} \mathrm{C}$ for a period of 120 days, and analyzes were performed at $15,30,45,60,90$ and 120 days. The determination of the TOS and the TAC were performed by colorimetric methods. Results: The results show that the two storage temperatures were able to preserve oxidants and antioxidants up to 60 days with similar levels when compared with fresh samples. When comparing the different storage temperatures at each time point, no significant differences were observed. Finally, the OSI remains constant over time of storage at both temperatures without statistically significant differences between them. The results were expressed as mean \pm standard error of mean. Statistical analysis was performed using the repeated-measures analysis of variance (ANOVA), the Bonferroni and t-test. A p-value $<0.05$ was accepted to be statistically significant. Conclusion: The two temperatures were able to keep salivary TOS and TAC levels similar to fresh saliva samples. Therefore they are reliable for assessing oxidative stress up to 60 days.
Received: August 3, 2018

Accepted: March 29, 2019

Address for correspondence Prof. Dr. José M. Amenábar, Universidade Federal do Paraná Stomatology Department, Oral Biochemistry Laboratory - LABIO Av. Lothário Meissner 632, Jardim Botânico. Curitiba-Paraná-Brazil. CEP: 80210-170.

Telephone: +55-41-3360-4024

Fax: +55-41-3360-4053 jamenaba@ufpr.br

Key words

Saliva; Freezing; Antioxidants; Oxidative Stress

\section{Introduction}

The use of saliva to measure oxidative stress (OS) is increasing (1), since researchers have demonstrated that saliva contains oxidation biomarkers similar to those in blood (25). The analysis of OS biomarkers in saliva is potentially valuable because its collection is simple and may provide a costeffective approach for the screening of large populations (6).

Nevertheless, sometimes saliva samples are required to be stored for several days and different results can be obtained because salivary constituents may degrade when processed after multiple freeze-thaw cycles or after different time and temperature of storage (7).

Since there is little consistency in the literature regarding the feasibility of saliva storage before OS markers analysis, the aim of this study was to compare the effects of short-term storage in two different temperatures on stability of salivary
Uvod

Korištenje sline za mjerenje oksidacijskoga stresa (OS-a) u porastu je (1) jer su istraživači pokazali da sadržava oksidacijske biomarkere slične onima u krvi $(2-5)$. Analiza biomarkera OS-a u slini potencijalno je vrijedna jer je njezino prikupljanje jednostavno i može biti ekonomična u slučaju probira u velikim populacijama (6).

Ipak, katkad je potrebno pohraniti uzorke sline nekoliko dana, no pritom se mogu dobiti različiti rezultati jer se njezini sastojci mogu razgraditi nakon više ciklusa zamrzavanja i odmrzavanja ili nakon različitih razdoblja i temperatura skladištenja (7).

Budući da u literaturi nema konzistentnosti kad je riječ o izvedivosti skladištenja sline prije analize markera OS-a, cilj ovog istraživanja bio je usporediti utjecaj kratkotrajnog skladištenja na dvjema različitim temperaturama na stabilnost 
total antioxidant capacity (TAC), total oxidant status (TOS) and oxidant stress index (OSI).

\section{Material and methods}

\section{Ethics Committee Approval}

The study protocol was approved by the Research Ethics Committee of the Federal University of Paraná, Brazil (Project CEP:872583/2014). All the participants received detailed information concerning the nature and the procedures involved in the study and signed informed consent forms.

This analytic study included saliva samples from 20 healthy volunteers, with an age range of $28-38$ years, recruited from February until July 2015.

\section{Saliva Collection and Storage}

Saliva production was stimulated by chewing a paraffin gum and total saliva samples were collected in plastic tubes on ice, after $2 \mathrm{hr}$-fasting, always between 8:00 and 10:00 a.m. Each participant collected saliva for approximately $10 \mathrm{~min}$ utes. All the samples were centrifuged at 2,600g for $10 \mathrm{~min}$ at $4^{\circ} \mathrm{C}$ to remove cellular and food debris and none of them were contaminated with blood.

Each saliva sample was divided in 13 identical aliquots $(500 \mu \mathrm{L})$. One aliquot was used immediately to analyze fresh saliva and two series of 6 identical aliquots were used to analyze after $15,30,45,60,90$ and 120 days of storage at $-20^{\circ} \mathrm{C}$ or $-80^{\circ} \mathrm{C}$.

\section{Saliva Analysis}

\section{Measurement of the TAC of the saliva}

Saliva TAC was determined using the automated colorimetric measurement method of Erel (8). In this method hydroxyl radicals react with O-dianisidine to produce the bright yellowish brown dianisyl radical and after the addition of saliva, the oxidative reactions are suppressed by the antioxidant components of saliva thus preventing the color change. The results were expressed as millimolar Trolox equivalent per liter (mmol Trolox equiv/L).

Measurement of the TOS of the saliva

Saliva TOS was measured using the fully automated colorimetric method of Erel (9). In this method, the oxidants present in saliva oxidize the ferrous ion -o-dianisidine complex to ferric ion. The results were expressed in terms of micromolar hydrogen peroxide equivalent per liter $\left(\mu \mathrm{mol} \mathrm{H}_{2} \mathrm{O}_{2}\right.$ Equiv/L).

\section{Oxidative stress index}

The percent ratio of the TOS to the TAS gives the oxidative stress index (OSI). To perform the calculation, the result unit of TAS, mmol Trolox Equivalent/L, was changed to $\mu \mathrm{mol}$ Trolox Equivalent/L, and the OSI value was calculated as follows: OSI $=[(\mathrm{TOS}, \mu \mathrm{mol} / \mathrm{L}) / \mathrm{TAS}, \mu \mathrm{mol} / \mathrm{L}) / 100]$

\section{Statistical analysis}

The results were expressed as mean \pm standard error of mean. Statistical analysis was performed using the repeated- ukupnog antioksidacijskog kapaciteta sline (TAC-a) i ukupnog oksidacijskog statusa (TOS-a) te na indeks oksidacijskoga stresa (OSI).

\section{Materijali i metode}

\section{Odobrenje Etičkog povjerenstva}

Protokol istraživanja odobrilo je Etičko povjerenstvo za istraživanje Saveznoga sveučilišta u Parani, Brazil (projekt CEP: 872583/2014).

Svi sudionici u istraživanju detaljno su informirani o njegovoj prirodi i postupcima te su potpisali informirani pristanak.

Ovo analitičko istraživanje uključivalo je uzorke sline prikupljene od veljače do srpnja 2015. godine od 20 zdravih dobrovoljaca u dobi od 28 do 38 godina.

\section{Prikupljanje i skladištenje sline}

Proizvodnja sline stimulirana je žvakanjem parafinske gume, a uzorci su skupljani u plastične epruvete na ledu, nakon dva sata posta, uvijek između 8,00 i 10,00 sati. Svaki sudionik skupljao je slinu približno 10 minuta. Svi su uzorci centrifugirani na 2,600 g 10 minuta na $4{ }^{\circ} \mathrm{C}$ da bi se uklonili ostaci stanica i hrane. Ni jedan nije bio kontaminiran krvlju.

Svaki uzorak sline podijeljen je na 13 identičnih alikvota $(500 \mathrm{uL})$. Jedan alikvot odmah je upotrijebljen za analizu svježe sline, a dvije serije od 6 identičnih alikvota korištene su za analizu nakon 15, 30, 45, 60, 90 i 120 dana skladištenja na $-20{ }^{\circ} \mathrm{C}$ ili $-80^{\circ} \mathrm{C}$.

\section{Analiza sline}

\section{Mjerenje TAC-a sline}

TAC sline određen je s pomoću automatizirane kolorimetrijske metode mjerenja prema Erelu (8). Pri primjeni ove metode hidroksilni radikali reagiraju s o-dianisidinom kako bi se proizveo svijetložućkastosmeđi radikal dianisil, a nakon dodavanja sline oksidacijske reakcije potiskuju antioksidacijske komponente sline čime se sprječava promjena boje. Rezultati su izraženi kao milimolarni ekvivalent troloksa po litri (mmol Trolox equiv/L).

\section{Mjerenje TOS-a sline}

TOS sline mjeren je uporabom potpuno automatizirane kolorimetrijske metode prema Erelu (9). U ovoj metodi oksidansi u slini oksidiraju kompleks iona o-dianisidina u željezov ion. Rezultati su izraženi u mikromolarnom ekvivalentu vodikova peroksida po litri $\left(\mu \mathrm{mol} \mathrm{H}_{2} \mathrm{O}_{2}\right.$ Equiv/L).

\section{Indeks oksidacijskog stresa}

Postotni omjer TOS-a prema TAS-u daje indeks oksidacijskog stresa (OSI). U izračunu jedinica rezultata TAS-a, mmol Trolox equiv/L, promijenjen je u $\mu$ mol Trolox equiv/L, a vrijednost OSI-ja izračunata je na sljedeći način: OSI = [(TOS, $\mu \mathrm{mol} / \mathrm{L}) / \mathrm{TAS}, \mu \mathrm{mol} / \mathrm{L}) / 100]$.

\section{Statistička analiza}

Rezultati su izraženi kao srednja vrijednost \pm standardna pogreška srednje vrijednosti. Statistička analiza obavljena 
measures analysis of variance (ANOVA), the Bonferroni and t-test. A p-value $<0.05$ was accepted to be statistically significant. Statistical analysis was performed with Statistical Package for the Social Sciences for Windows (SPSS, version 20.0, SPSS Inc., Chicago, IL, USA).

\section{Results}

Compared with fresh saliva samples, salivary TAC and TOS levels were significantly lower after 90 days of storage at both temperatures (Figure 1 and Figure 2). Saliva TOS concentration presented a long term decline during the study at both temperatures. There was a statistically significant effect of time on TOS levels at $-20^{\circ} \mathrm{C}, \mathrm{F}(11.26,2.21)=5.09$, $\mathrm{p}=0.002, \eta_{\mathrm{p}}^{2}=0.253$; with difference between $\mathrm{T} 0$ and $\mathrm{T} 90$ $(\mathrm{p}=0.02)$ and at $-80^{\circ} \mathrm{C}, \mathrm{F}(12.08,2.11)=5.716, \mathrm{p}=0.001$, $\eta_{p}^{2}=0.276$; with difference between T0 and T90 ( $\left.\mathrm{p}=0.03\right)$.

Saliva TAC concentration also presented a long term decline at both temperatures with statistical significant effect, at $-20^{\circ} \mathrm{C}, \mathrm{F}(5.71,2.13)=2.67, \mathrm{p}=0.02, \eta^{2}=0.151$; with difference between $\mathrm{T} 0$ and $\mathrm{T} 90(\mathrm{p}=0.012)$ and at $-80^{\circ} \mathrm{C}, \mathrm{F}(17.025$, $2.50)=6.80, \mathrm{p}<0.001, \eta_{\mathrm{p}}^{2}=0.312$; with difference between $\mathrm{T} 0$ and T90 ( $\mathrm{p}=0.02)$.

On the other hand, no statistical difference was found between the two temperatures of storage at each different time points for TAC and TOS, as shown on Table 1 and Table 2. Also, no statistical difference was found in the OSI level between the two storage temperatures, remaining practically constant during the period of the study (Table 3). je analizom varijance (ANOVA) te Bonferronijevim i t-testom. P-vrijednost $<0,05$ prihvaćena je kao statistički značajna. Statistička analiza provedena je Windowsovim statističkim paketom za društvene znanosti (SPSS, verzija 20.0, SPSS Inc., Chicago, IL, SAD).

\section{Rezultati}

U usporedbi s uzorcima svježe sline, razine TAC-a iTOSa bile su značajno niže nakon 90 dana skladištenja na objema temperaturama (slika 1. i slika 2.). Koncentracija TOSa u slini dugoročno je pokazala pad tijekom istraživanja na objema temperaturama. Utvrđen je statistički značajan utjecaj vremena na TOS-ove razine na $-20{ }^{\circ} \mathrm{C}, \mathrm{F}(11,26,2,21)=$ $5,09, \mathrm{p}=0,002, \eta 2 \mathrm{p}=0,253$; s razlikom između T0 i T90 (p $=0,02)$ i na $-80{ }^{\circ} \mathrm{C}, \mathrm{F}(12,08,2,11)=5,716, \mathrm{p}=0,001, \eta 2 \mathrm{p}$ $=0,276 ; s$ razlikom između T0 i T90 $(\mathrm{p}=0,03)$.

U koncentraciji TAC-a u slini također je zabilježen pad na objema temperaturama sa statistički značajnim utjecajem, na $-20^{\circ} \mathrm{C}, \mathrm{F}(5,71,2,13)=2,67, \mathrm{p}=0,02, \eta 2 \mathrm{p}=0,151$; $\mathrm{s}$ razlikom između T0 i T90 ( $\mathrm{p}=0,012)$ i na $-80^{\circ} \mathrm{C}, \mathrm{F}(17,025$, $2,50)=6,80, p<0,001, \eta 2 p=0,312 ; s$ razlikom izmedu T0 i T90 (p = 0,02).

No, nisu pronađene statistički značajne razlike između dviju temperatura skladištenja u različitim vremenskim točkama za TAC i TOS, kao što je prikazano u tablici 1 . i tablici 2. Također nije pronađena statistički značajna razlika u razinama OSI-ja koje su ostale praktički konstantne tijekom istraživanja između obiju temperatura skladištenja (tablica 3.).

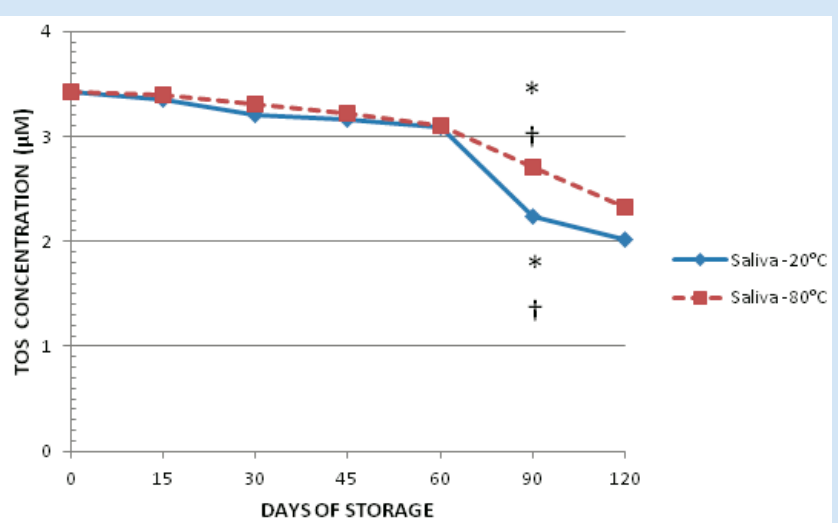

Figure 1 The effect of storage at $-20^{\circ} \mathrm{C}$ and $-80^{\circ} \mathrm{C}$ for 120 days on salivary TAC concentration. ${ }^{*} \mathrm{p}<0.05$ is significantly different from the previous month. $\dagger p<0.05$ is significantly different from day 0 .

Slika 1. Utjecaj skladištenja na $-20^{\circ} \mathrm{C} \mathrm{i}-80^{\circ} \mathrm{C}$ tijekom 120 dana na salivarnu koncentraciju TAC-a; ${ }^{\star} p<0,05$ statistički je značajno različit u odnosu prema prethodnom mjesecu; $\dagger p<0,05$ statistički je značajno različit u odnosu prema nultom danu

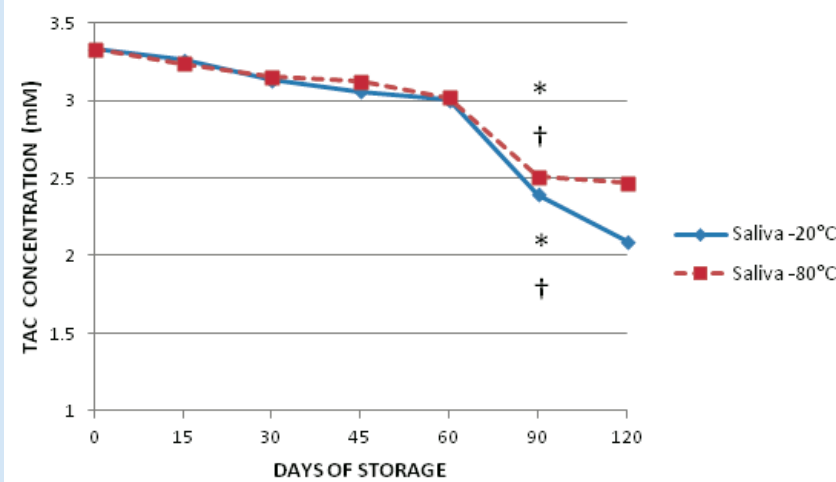

Figure 2 The effect of storage at $-20^{\circ} \mathrm{C}$ and $-80^{\circ} \mathrm{C}$ for 120 days on salivary TOS concentration. ${ }^{*} \mathrm{p}<0.05$ is significantly different from the previous month. $\uparrow p<0.05$ is significantly different from day 0 .

Slika 2. Utjecaj skladištenja na $-20^{\circ} \mathrm{C} \mathrm{i}-80^{\circ} \mathrm{C}$ tijekom 120 dana na salivarnu koncentraciju TOS-a; ${ }^{\star} p<0,05$ statistički je značajno različit u odnosu prema prethodnom mjesecu; t $p<0,05$ statistički je značajno različit u odnosu prema nultom danu 
Table 1 Comparison of the total antioxidant capacity (mmol Trolox equiv $/ \mathrm{L}$ ) of saliva stored at $-20^{\circ} \mathrm{C}$ and at $-80^{\circ} \mathrm{C}$ at different time points.

Tablica 1. Usporedba ukupnog oksidacijskog kapaciteta (mmol Trolox equiv/L) sline skladištene na $-20^{\circ} \mathrm{C} \mathrm{i}-80^{\circ} \mathrm{C} \mathrm{u}$ različitim vremenskim točkama

Fresh saliva • Svježa slina

\begin{tabular}{|c|c|c|c|}
\hline \multirow[t]{2}{*}{ Fresh saliva $\bullet$ Svježa slina } & \multicolumn{2}{|c|}{$3.53 \pm 0.72$} & \multirow[b]{2}{*}{$\mathbf{p}$} \\
\hline & $\begin{array}{c}\text { Freezing at }-20^{\circ} \mathrm{C} \cdot \\
\text { Zamrzavanje na }-20^{\circ} \mathrm{C}\end{array}$ & $\begin{array}{c}\text { Freezing at }-80^{\circ} \mathrm{C} \bullet \\
\text { Zamrzavanje na }-80^{\circ} \mathrm{C}\end{array}$ & \\
\hline 15 Days $\bullet 15$ dana & $3.42 \pm 1.08$ & $3.23 \pm 1.07$ & 0.665 \\
\hline 30 Days $\bullet 30$ dana & $3.13 \pm 1.47$ & $3.15 \pm 1.53$ & 0.626 \\
\hline 45 Days $\bullet 45$ dana & $3.05 \pm 1.32$ & $3.12 \pm 1.48$ & 0.813 \\
\hline 60 Days $\bullet 60$ dana & $3.00 \pm 1.25$ & $3.02 \pm 1.53$ & 0.852 \\
\hline 90 Days $\bullet 90$ dana & $2.39 \pm 1.29$ & $2.50 \pm 1.22$ & 0.765 \\
\hline 120 Days $\bullet 120$ dana & $2.09 \pm 1.51$ & $2.47 \pm 1.00$ & 0.802 \\
\hline
\end{tabular}

Table 2 Comparison of the total oxidant status ( $\mu \mathrm{mol} \mathrm{H} \mathrm{H}_{2} \mathrm{O}_{2}$ equiv $/ \mathrm{L}$ ) of saliva stored at $-20^{\circ} \mathrm{C}$ and at $-80^{\circ} \mathrm{C}$ at different time points.

Tablica 2. Usporedba ukupnog oksidacijskog statusa ( $\mu \mathrm{mol}^{2} \mathrm{H}_{2} \mathrm{O}_{2}$ equiv / $\mathrm{L}$ ) sline skladištene na $-20^{\circ} \mathrm{C}$ i na $-80^{\circ} \mathrm{C}$ u različitim vremenskim točkama

Fresh saliva • Svježa slina

Fresh saliva $\bullet$ Svježa sina
Freezing at $-20^{\circ} \mathrm{C} \bullet$
Zamrzavanje na $-20^{\circ} \mathrm{C}$

\begin{tabular}{c|c|c|c} 
& Zamrzavanje na $-\mathbf{2 0} \mathbf{C}$ & $3.40 \pm 1.06$ & 0.731 \\
\hline 15 Days $\bullet$ 15 dana & $3.35 \pm 0.96$ & $3.31 \pm 1.13$ & 0.118 \\
\hline 30 Days $\bullet 30$ dana & $3.21 \pm 1.22$ & $3.21 \pm 1.02$ & 0.191 \\
\hline 45 Days $\bullet$ 45 dana & $3.15 \pm 1.32$ & $3.10 \pm 0.13$ & 0.846 \\
\hline 60 Days $\bullet$ 60 dana & $3.09 \pm 0.87$ & $2.70 \pm 1.27$ & 0.633 \\
\hline 90 Days $\bullet 9$ dana & $2.24 \pm 0.78$ & $2.32 \pm 0.76$ & 0.796 \\
\hline 120 Days $\cdot 120$ dana & $2.02 \pm 0.70$ &
\end{tabular}

Table 3 Comparison of the oxidative stress index of saliva stored at $-20^{\circ} \mathrm{C}$ and at $-80^{\circ} \mathrm{C}$ at different time points.

Tablica 3. Usporedba indeksa oksidacijskog stresa sline skladištene na $-20^{\circ} \mathrm{C}$ i na $-80^{\circ} \mathrm{C}$ u različitim vremenskim točkama.

Fresh saliva • Svježa slina

12

Freezing at $-20^{\circ} \mathrm{C} \cdot$ Zamrzavanje na $-20^{\circ} \mathrm{C}$

15 Days $\bullet 15$ dana

30 Days $\bullet 30$ dana

45 Days $\bullet 45$ dana

60 Days $\bullet 60$ dana

90 Days $\bullet 90$ dana

120 Days $\bullet 120$ dana

$10.24 \pm 1.55$

$10.31 \pm 1.94$

$10.30 \pm 1.89$

$9.36 \pm 1.18$

$9.65 \pm 1.6$
$9.71 \pm 1.64$

Freezing at $-80^{\circ} \mathrm{C} \cdot$

Zamrzavanje na $-80^{\circ} \mathrm{C}$

p

\begin{tabular}{l|l}
$10.50 \pm 1.88$ & 0.673 \\
\hline
\end{tabular}

\begin{tabular}{l|l}
$10.49 \pm 1.78$ & 0.233
\end{tabular}

$10.30 \pm 2.05$

$10.29 \pm 1.83$

$10.77 \pm 1.03$

$9.39 \pm 1.23$

.673

.233

\section{Rasprava}

Slina se sve više koristi kao dijagnostički medij jer je metoda prikupljanja jednostavna i neinvazivna, uzorkovanje se može ponoviti i prikladna je za istraživanje pojedinačnih analita ili složenih mjerenja (10). Također se navodi da je slina prikladna za otkrivanje razine oksidacijskog stresa u tijelu te može pomoći u dijagnozi, prognozi i terapijskom odgovoru kad je riječ o bolestima ljudi $(10-12)$. No neki analiti sline nisu stabilni na sobnoj temperaturi i i često je potrebno čuvanje uzoraka prije analize (10). Koliko znamo, ovo je prvo istraživanje koje procjenjuje stabilnost TAC-a, TOS-a i OSI-ja sline tijekom skladištenja na dvjema temperaturama $\left(-20{ }^{\circ} \mathrm{C}\right.$ i $\left.-80{ }^{\circ} \mathrm{C}\right)$, procjenjujući varijacije koje se događaju svih 120 dana skladištenja.

Prema našim rezultatima, razdoblja skladištenja potaknula su određene promjene TAC-a i TOS-a, bez obzira na temperaturu skladištenja. Čini se da se slina može zamrznuti i pohraniti na $-20^{\circ} \mathrm{C}$ ili $-80{ }^{\circ} \mathrm{C}$ dva mjeseca kako bi se postigli slični rezultati kao i s uzorcima svježe sline. results to the ones found in fresh saliva samples. 
In this study, the saliva TAC decreased with a similar pattern, regardless of the storage temperature. This decrease can be explained by the fact that some of the antioxidants comprise proteins and it is a known fact that temperature has a strong influence on the activity of proteins in which lower temperatures result in lower activity. One limitation of the present study is that we did not quantify proteins in the samples; therefore we cannot confirm that this did not interfere with the results. One of the reasons for the decrease in TAC measurements may be the loss of protein activity or protein degradation. Hubel et al.(13), on a review evaluated various fluids, including urine, saliva, blood, among others, shows that different conditions of collection and storage have great effects on the stability of proteins, leading to misinterpretation of the results and invalid conclusions. Emekli-Alturfan $e t$ al. $(7,14)$ evaluated the levels of GSH and lipid peroxidation in saliva samples stored at $-20^{\circ} \mathrm{C}$, in $30,60,90,120,150$ and 180 days after collection. They suggest that saliva can be stored for 30 days at $-20^{\circ} \mathrm{C}$. Also, $\mathrm{Ng}$ et al. (15) analyzed salivary $\operatorname{IgA}$ and lysozyme and they observed that the concentrations remain stable for up to 3 months when stored at $-30^{\circ} \mathrm{C}$.

The evaluation of oxidative status during storage has been made in other body fluids such as urine, breast milk and blood. Remer et al.(16) used urine which was stored for a period of 15 years and they found that some substances have high stability at $-22^{\circ} \mathrm{C}$, such as uric acid, a non-enzymatic antioxidant. However, other substances such as oxalate had losses over time and to prevent this, the use of preservatives has been proposed. Nevertheless, adding preservatives can interfere with other saliva compounds.

Akdag et al. (17) assessed the stability of TAC in breast milk stored at $-80^{\circ} \mathrm{C}$ for 3 months and found that it remains stable without significant losses. Silvestre et al. (18) evaluated the activity of glutathione peroxidase and the concentration of MDA in breast milk in 2 temperatures $\left(-20^{\circ} \mathrm{C}\right.$ and $\left.-80^{\circ} \mathrm{C}\right)$, at 15,30 and 60 days of storage. They found that freezing induces losses in the antioxidant properties of breast milk and that such losses increase with duration of storage and differ in intensity according to temperature. They suggests that in order to maximally preserve the antioxidant properties of breast milk, the latter should be stored at $-80{ }^{\circ} \mathrm{C}$ degrees for a period of less than 30 days, rather than for shorter time periods at usual temperature of $-20{ }^{\circ} \mathrm{C}$ degrees (18).

In the present study, regardless of the storage temperature, the saliva TAC and TOS decreased with a similar pattern. However, saliva stored at $-80^{\circ} \mathrm{C}$ seems to be more stable than saliva stored at $-20^{\circ} \mathrm{C}$. Consequently, the general and widely accepted rule of storing at the lowest temperature possible seems to apply to the saliva TAC and TOS, as might be expected. On the other hand, if saliva cannot be stored at $-80^{\circ} \mathrm{C}$, it can be stored at $-20^{\circ} \mathrm{C}$ for 60 days without interfering with the TAC, TOS and OSI levels.

The limitations of our study are a relatively small sample size and the fact that only TAC and TOS were analyzed. Although specific biomarkers should be examined to clearly identify oxidative stress, the assessment of oxidative stress through the evaluation of the TAC and TOS may be sensible to elucidate the oxidant status and the preservation of the samples.
U ovom istraživanju TAC sline smanjio se prema sličnom obrascu, bez obzira na temperaturu skladištenja. To se može objasniti činjenicom da neki od antioksidansa sadržavaju proteine, a poznata je činjenica da temperatura snažno utječe na aktivnost proteina u kojima niže temperature rezultiraju manjom aktivnošću. Jedno od ograničenja ovog istraživanja jest da nismo kvantificirali proteine u uzorcima i zato ne možemo potvrditi da to nije utjecalo na rezultate. Jedan od razloga za smanjenje TAC-a može biti i gubitak aktivnosti proteina ili njihova degradacija. Hubel i suradnici (13) na temelju ocjene različitih tekućina, uključujući urin, slinu i krv, ističu da različiti uvjeti skupljanja i skladištenja imaju velik učinak na stabilnost proteina, što rezultira pogrešnim tumačenjem rezultata i nevaljanim rezultatima. Emekli-Alturfan i suradnici $(7,14)$ procijenili su razine $\mathrm{GSH}$-a i lipidne peroksidacije u uzorcima sline pohranjenima na $-20^{\circ} \mathrm{C} 30,60,90,120$, 150 i 180 dana poslije prikupljanja. Oni sugeriraju da se slina može čuvati 30 dana na $-20^{\circ} \mathrm{C}$. Ng i suradnici (15) također su analizirali salivarni IgA i lizozim te su uočili da koncentracije ostaju stabilne do tri mjeseca ako se čuvaju na $-30{ }^{\circ} \mathrm{C}$.

Procjena oksidacijskog statusa tijekom skladištenja obavljena je i u drugim tjelesnim tekućinama, kao što su urin, majčino mlijeko i krv. Remer i suradnici (16) koristili su se urinom koji je čuvan 15 godina i otkrili su da neke tvari zadržavaju visoku stabilnost na $-22^{\circ} \mathrm{C}$, kao što su mokraćna kiselina i neenzimski antioksidans. No za druge tvari, kao što je oksalat, zabilježen je gubitak tijekom vremena i, kako bi se to spriječilo, predložena je upotreba konzervansa. No dodavanje konzervansa može utjecati na druge spojeve u slini.

Akdag i suradnici (17) procijenili su stabilnost TAC-a u majčinu mlijeku pohranjenom tri mjeseca na $-80{ }^{\circ} \mathrm{C}$ i utvrdili da je stabilan i bez značajnih gubitaka. Silvestre i suradnici (18) procijenili su aktivnost glutation peroksidaze i koncentraciju MDA-e u majčinu mlijeku na dvjema temperaturama $\left(-20{ }^{\circ} \mathrm{C}\right.$ i $\left.-80{ }^{\circ} \mathrm{C}\right)$ nakon 15,30 i 60 dana skladištenja. Otkrili su da zamrzavanje uzrokuje gubitak antioksidacijskih svojstava majčina mlijeka i da se takvi gubitci povećavaju s trajanjem skladištenja i razlikuju se u intenzitetu prema temperaturi. Predlažu, kako bi se maksimalno sačuvala antioksidacijska svojstva majčina mlijeka, da ga treba čuvati na $-80^{\circ} \mathrm{C}$ u razdoblju kraćem od 30 dana, a ne u kraćim razdobljima na uobičajenoj temperaturi od $-20^{\circ} \mathrm{C}(18)$.

$\mathrm{U}$ ovom istraživanju, bez obzira na temperaturu skladištenja, TAC i TOS sline smanjili su se prema sličnom uzorku. No čini se da je slina pohranjena na $-80^{\circ} \mathrm{C}$ stabilnija od one pohranjene na $-20^{\circ} \mathrm{C}$. Prema tome, čini se da je općeprihvaćeno pravilo o skladištenju na najnižoj mogućoj temperaturi primjenjivo i na TAC i TOS u slini, kao što se moglo i očekivati. Ako se slina ne može pohraniti na $-80{ }^{\circ} \mathrm{C}$, može se 60 dana čuvati na $-20^{\circ} \mathrm{C}$ bez promjena u razinama TAC-a, TOS-a i OSI-ja.

Ograničenja našeg istraživanja razmjerno su mala veličina uzorka i činjenica da su analizirani samo TAC i TOS. Iako bi se trebali ispitati specifični biomarkeri kako bi se jasno identificirao oksidacijski stres, njegova procjena na temelju analize TAC-a i TOS-a može biti indikativna za rasvjetljavanje oksidacijskog statusa i kvalitetu čuvanja uzoraka. 


\section{Conclusion}

The present results confirm that salivary TOS, TAC and OSI are preserved in samples stored up to 60 days, regardless of temperature. Further research is needed to determine if specific antioxidants are also preserved during this period of storage at both temperatures.

\section{Acknowledgements}

This study was supported by the Coordination for the Improvement of Higher Level Education Personnel (CAPES)

\section{Conflict of interest}

The authors declare no conflict of interest.

\section{Zaključak}

Ovi rezultati potvrđuju da se TOS, TAC i OSI u slini zadržavaju u uzorcima pohranjenima do 60 dana, bez obzira na temperaturu. Potrebna su daljnja istraživanja kako bi se ustanovilo jesu li i specifični antioksidansi očuvani tijekom tog razdoblja skladištenja.

\section{Zahvala}

Ovo istraživanje poduprla je Koordinacija za poboljšanje kadrova za visoko obrazovanje (CAPES).

\section{Sukob interesa}

Autori ne navode sukob interesa.

\begin{abstract}
Sažetak
Cilj: Cilj ovog istraživanja bio je usporediti utjecaj kratkotrajnog skladištenja sline na dvjema različitim temperaturama na stabilnost ukupnog antioksidacijskog kapaciteta (TAC) i ukupnog oksidacijskog statusa (TOS) te na indeks oksidacijskog stresa (OSI). Materijali i metode: Uzorak sline za ispitivanje prikupljen je od 20 zdravih dobrovoljaca. Alikvot je odabran za trenutačnu analizu, a ostatak je bio pohranjen 120 dana na temperaturama od $-20^{\circ} \mathrm{C}$ i $-80^{\circ} \mathrm{C}$. Analize su obavljene nakon 15,30 45, 60, 90 i 120 dana. Odredivanje TOS-a i TAC-a provedeno je kolorimetrijskim metodama. Rezultati: Rezultati pokazuju da su se na obje temperature skladištenja mogli očuvati oksidansi i antioksidansi do 60 dana i da su im, u usporedbi sa svježim uzorcima, razine ostale slične. Pri uspoređivanju različitih temperatura skladištenja u svakoj vremenskoj točki, nisu uočene statistički značajne razlike. Naposljetku, OSI je ostao konstantan tijekom skladištenja na objema temperaturama, bez statistički značajnih razlika. Rezultati su izraženi kao srednja vrijednost \pm standardna pogreška. Statistička analiza obavljena je analizom varijance (ANOVA) te Bonferronijevim i t-testom. P-vrijednost < 0,05 prihvaćena je kao statistički značajna. Zaključak: Obje temperature bile su u stanju održati slične razine TOS-a i TAC-a u uzorcima svježe sline. Zato su pouzdani za procjenu oksidativnog/oksidacijskog stresa do 60 dana.
\end{abstract}

Zaprimljen: 3. kolovoza 2018 Prihvaćen: 29. ožujka 2019.

Adresa za dopisivanje prof. dr. sc. José M. Amenábar, Universidade Federal do Paraná Stomatology Department, Oral Biochemistry Laboratory - LABIO Av. Lothário Meissner 632, Jardim Botânico. Curitiba-Paraná-Brazil. CEP: $80210-170$.

tel.: $+55-41-3360-4024$. faks.: $+55-41-3360-4053$. jamenaba@ufpr.br

Ključne riječi slina; zamrzavanje; antioksidansi; oksidativni stres

\section{References}

1. Buczko P, Zalewska A, Szarmach I. Saliva and oxidative stress in oral cavity and in some systemic disorders. J Physiol Pharmacol. 2015 Feb;66(1):3-9.

2. Ho E, Karimi Galougahi K, Liu CC, Bhindi R, Figtree GA. Biological markers of oxidative stress: applications to cardiovascular research and practice. Redox Biol. 2013 Oct 8;1:483-91.

3. de Almeida C, Amenábar JM. Changes in the salivary oxidative status in individuals with temporomandibular disorders and pain. $J$ Oral Biol Craniofac Res. 2016 Nov;6(Suppl 1):S1-S4.

4. Madi M, Babu S, Kumari S, Shetty S, Achalli S, Madiyal A, et al. Status of Serum and Salivary Levels of Superoxide Dismutase in Type 2 Diabetes Mellitus with Oral Manifestations: A Case Control Study. Ethiop J Health Sci. 2016 Nov;26(6):523-532.

5. Ahmadi-Motamayel F, Goodarzi MT, Jamshidi Z, Kebriaei R. Evaluation of Salivary and Serum Antioxidant and Oxidative Stress Statuses in Patients with Chronic Periodontitis: A Case-Control Study. Front Physiol. 2017 Mar 31;8:189.

6. Kaufman E, Lamster IB. The diagnostic applications of saliva - a review. Crit Rev Oral Biol Med. 2002;13:197-212.

7. Emekli-Alturfan E, Kasikci E, Alturfan AA, Pisiriciler R, Yarat A. Effect of sample storage on stability of salivary glutathione, lipid peroxidation levels, and tissue factor activity. J Clin Lab Anal. 2009;23(2):93-8.

8. Erel O. A novel automated method to measure total antioxidant response against potent free radical reactions. J Clin Lab Anal. 2009;23(2):93-8.

9. Erel O. A new automated colorimetric method for measuring total oxidant status. Clin Biochem. 2005 Dec;38(12):1103-11.

10. Wang J, Schipper HM, Velly AM, Mohit S, Gornitsky M. Salivary biomarkers of oxidative stress: A critical review. Free Radic Biol Med. 2015;85:95-104.
11. Peluso I, Raguzzini A. Salivary and Urinary Total Antioxidant Capacity as Biomarkers of Oxidative Stress in Humans. Patholog Res Int. 2016;2016:5480267.

12. Tartaglia GM, Gagliano N, Zarbin L, Tolomeo G, Sforza C. Antioxidant capacity of human saliva and periodontal screening assess ment in healthy adults. Arch Oral Biol. 2017 Jun;78:34-38.

13. Hubel A, Aksan A, Skubitz AP, Wendt C, Zhong X. State of the art in preservation of fluid biospecimens. Biopreserv Biobank. 2011 Sep;9(3):237-44

14. Emekli-Alturfan E, Yarat A, Çalışkan-Ak E, Pisiriciler R, Kuru B, Noyan Ü. Determination of storage time of saliva samples obtained from patients with and without chronic periodontitis for the comparison of some biochemical and cytological parameters. J Clin Lab Anal. 2013;27:261-266.

15. Ng V, Koh D, Fu Q, Chia SE. Effects of storage time on stability of salivary immunoglobulin A and lysozyme. Clin Chim Acta. 2003 Dec;338(1-2):131-4.

16. Remer T, Montenegro-Bethancourt G, Shi L. Long-term urine biobanking: storage stability of clinical chemical parameters under moderate freezing conditions without use of preservatives. Clin Biochem. 2014 Dec;47(18):307-11.

17. Akdag A, Nur-Sari F, Dizdar EA, Uras N, Isikoglu S, Erel O, et al. Storage at $-80^{\circ} \mathrm{C}$ preserves the antioxidant capacity of preterm human milk. J Clin Lab Anal. 2014 Sep;28(5):415-8.

18. Silvestre D, Miranda M, Muriach M, Almansa I, Jareño E, Romero FJ. Frozen breast milk at -20 degrees $C$ and -80 degrees $C$ : $A$ longitudinal study of glutathione peroxidase activity and malondialdehyde concentration. J Hum Lact. 2010 Feb;26(1):35-41. 